\title{
Sistem Informasi Geografis Wisata Religi Berbasis Web Mobile
}

\author{
Nur Vinandari ${ }^{1)}$, Khairul Anwar Hafizd ${ }^{2}$, Muhammad Noor ${ }^{3)}$ \\ ${ }^{122) 3)}$ Jurusan Teknik Informatika, Politeknik Negeri Tanah Laut \\ Jl. A. Yani Km 6 Pelaihari Tanah Laut Kalimantan Selatan \\ ${ }^{1)}$ nurvinandari97@gmail.com \\ ${ }^{2}$ khairul.anwarhafizd @gmail.com \\ ${ }^{3)}$ muhammadnoorpolitala@gmail.com
}

\begin{abstract}
Abstrak
Kabupaten Tanah Laut salah satu daerah andalan sektor objek wisata di Kalimantan Selatan. Kabupaten Tanah Laut memiliki berbagai potensi pariwisata salah satunya yaitu pada wisata religi. Wisata religi merupakan kegiatan wisata untuk mendapatkan kesenangan atau hiburan, juga akan mendapatkan pelajaran tentang ajaran-ajaran Islam serta menambah pengetahuan. Pemerintah Kabupaten Tanah Laut dalam melakukan promosi wisata masih menggunakan media masa seperti surat kabar dan pamflet, dimana metode tersebut belum cukup untuk menginformasikan objek wisata kepada wisatawan. Serta belum adanya sistem informasi geografis khusus mengenai wisata religi dan selain itu pada Dinas Pariwisata data-data mengenai wisata religi yang ada di beberapa kecamatan pada kabupaten tanah laut masih di katakan belum lengkap atau menyeluruh dalam pendataan tempat wisata religi. Tujuan dari penelitian dengan membuat perancangan dan membangun Sistem Informasi Geografis Wisata Religi yang dapat menampilkan gambaran peta dan memberikan informasi secara detail lokasi wisata religi di beberapa kecamatan pada kabupaten Tanah Laut. Penyajian informasi dalam bentuk web mobile yang diharapakanakanmembantu masyarakat untuk mengaksesnya dimana saja dan kapan saja. Pada sistem informasi geografis wisata religi dibangun dengan menggunakan bahasa pemrograman Hypertext Preprocessor (PHP) dan JavaScript.
\end{abstract}

Kata kunci: Sistem Informasi Geografis, Wisata Religi, Web Mobile.

\begin{abstract}
Tanah Laut is one of the mainstays of the tourist sector in South Kalimantan. Tanah Laut Regency has tourism potential, one of which is religious tourism. Religious tourism is a tourist activity to get fun or entertainment, also will get lessons about Islamic teachings and increase knowledge. The government of Tanah Laut regency conducting tourism promotions still through mass media such as newspapers and pamphlet methods is not enough to support tourist attractions for tourists. And there is no specific information system on religious tourism and besides that in the Tourism Office the data on religious tourism in several sub-districts in the regency of the sea are still not yet complete or complete in the data collection of religious tourism spots. The purpose of the research is to make a design and a Geographic Tourism Information System that can display a picture and provide detailed information on the location of religious tourism in several sub-districts in Tanah Laut district. Information in the form of a web mobile is expected to help the community to access it anywhere and anytime. In geographical information systems, religious tourism is built using the Hypertext Preprocessor (PHP) and JavaScript programming languages.
\end{abstract}

Keywords: Geographic Information System, Religious Tourism, Web Mobile. 


\section{PENDAHULUAN}

Sistem Informasi Geografis adalah suatu sistem yang dibuat berdasarkan pemetaan geografis bumi. Sistem ini dapat memberikan informasi mengenai letak dari lokasi tempat-tempat yang ada di permukaan bumi, serta memberikan keterangan-keterangan dari lokasi yang telah diberikan dan dapat memberikan informasi mengenai tempat lokasi wisata (Wahana Komputer, 2014).

Kabupaten Tanah Laut merupakan salah satu daerah andalan sektor objek wisata di Kalimantan Selatan. Kabupaten Tanah Laut terus mempromosikan objek wisata yang berguna untuk mendukung rencana dan visi Pemerintah Kabupaten Tanah Laut. Sebagai salah satu kabupaten yang ada di Kalimantan Selatan, Kabupaten Tanah Laut memiliki berbagai potensi pariwisata salah satunya wisata religi. Berdasarkan survei lapangan yang dilakukan pada 5 Maret - 30 Maret 2018, didapatkan hasil data wisata religi dari beberapa kecamatan seperti pada Tabel 1.

Tabel 1. Hasil pengumpulan data

\begin{tabular}{|c|c|c|c|c|c|c|}
\hline \multirow{2}{*}{ No. } & \multirow{2}{*}{ Nama Kecamatan } & \multicolumn{4}{|c|}{ Kategori } & \multirow{2}{*}{ Jumlah } \\
\hline & & Makam & Masjid & Majelis & Pesantren & \\
\hline 1. & Pelaihari & 1 & 2 & 4 & 3 & 10 \\
\hline 2. & Takisung & 2 & 1 & - & - & 3 \\
\hline 3. & Tambang Ulang & 1 & - & - & - & 1 \\
\hline 4. & Bati-Bati & 5 & - & 2 & 1 & 8 \\
\hline 5. & Batu Ampar & 2 & - & 1 & - & 3 \\
\hline 6. & Jorong & 1 & 1 & - & 1 & 3 \\
\hline 7. & Kintap & 3 & 1 & 3 & 1 & 8 \\
\hline
\end{tabular}

Wisata religi merupakan wisata yang berhubungan dengan aktifitas keagamaan, dimana pada wisata religi ini dimanfaatkan untuk menyebarkankan dakwah dan pembelajaran tentang islam ke masyarakat luas secara umum dalam bentuk kegiatan wisata, pada wisata religi masyarakat dapat melakukan liburan dan dapat mempelajari mengenai sejarah dari tempat wisata religi yang dikunjungi. Wisata religi tidak hanya sebatas berkaitan dengan ziarah ke makam tokoh-tokoh islam saja melainkan dapat mencakup setiap tempat keagamaan seperti berkunjung ke masjid, majelis, dan pondok pesantren yang berhubungan dengan sejarah, kegiatan-kegiatan/program dari tempat wisata religi yang mencakup mengenai kegiatan keagamaan (Chotib, 2015).

Pemerintah Kabupaten Tanah Laut melakukan promosi wisata melalui media masa seperti surat kabar, media sosial dan pamflet. Keberadaan metode tersebut untuk menginformasikan objek wisata secara meluas kepada wisatawan lokal maupun asing. Namun belum adanya sistem informasi geografis khusus untuk mempromosikan wisata religi yang ada di Kabupaten Tanah Laut dan selain itu berdasarkan data yang diperoleh pada Dinas Pariwisata data - data mengenai wisata religi yang ada di Kabupaten Tanah Laut masih dikatakan belum menyeluruh dalam pendataan khusus mengenai tempat wisata religi.

Adapun tujuan dari penelitian adalah dengan membuat perancangan dan membangun Sistem Informasi Geografis Wisata Religi. Dengan adanya sistem informasi geografis diharapkan dapat menampilkan gambaran peta dan titik koordinat peta serta info detail tempat wisata religi. Penyajian informasi dalam bentuk web mobile dibangun lebih menarik dan dapat dinikmati oleh masyarakat luas dandiharapkan dapat membantu masyarakat untuk bisa mengaksesnya dimana saja dan kapan saja. Pada sistem informasi geografis wisata religi dibangun dengan menggunakan bahasa pemrograman (HTML), Hypertext Preprocessor (PHP) dan Java Script.

Berdasarkan permasalahan yang ada maka penulis menuangkan dalam sebuah karya tulis yang berjudul "Sistem Informasi Geografis Wisata Religi Berbasis Web Mobile" pada pembuatan sistem informasi geografis diharapakan kita bisa mengetahui tentang lokasi-lokasi wisata yang dapat memberikan informasi secara detail bagi wisatawan yang ingin berkunjung ketempat wisata religi yang ada di beberapa kecamatan yaitu kecamatan Takisung, Tambang Ulang, Bati-Bati, Batu Ampar, Jorong, dan Kintap yang ada di Kabupaten Tanah Laut. Serta mengetahui tentang nilai-nilai keagamaan dan sejarah mengenai tempat wisata religi tersebut. 


\section{TINJAUAN PUSTAKA}

\subsection{Sistem Informasi Geografis}

Sistem Informasi Geografis adalah suatu sistem yang didesain secara efektif untuk menangkap, menyimpan, memanipulasi, menganalisis, mengatur dan menampilkan data dalam suatu informasi berbasis geografis (Irwansyah, 2013).

Sistem Informasi Geografis dapat menghubungkan berbagai data pada satu titik tertentu dibumi, menggabungkannya, men nganalisis, memetakan hasilnya dan menampilkannya dalam bentuk format grafik dan tabel. Data yang diolah pada Sistem Informasi Geografis adalah data spasial yaitu data beorientasi geografis dan merupakan lokasi yang memiliki sistem koordinat tertentu (Adil, 2017).

\subsection{Wisata Religi}

WisataReligi merupakan suatu perjalanan yang dilakukan oleh satu orang atau lebih dengan tujuan mengunjungi tempat-tempat yang memiliki nilai-nilai keagamaan atau sejarah keagamaan yang bertujuan untuk melakukan pengembangan pribadi, rekreasi dan mempelajari nilai-nilai keagamaan (Sari, Yasa, Darmawiguna, \& Sunarya, 2016).

\subsection{Web Mobile}

Web Mobile merupakan web atau halaman websiteinternet yang dapat digunakan atau di akses pada perangkat mobile. Agar website yang dibuat dapat diakses pada berbagai perangkat baik perangkat komputer secara umum (seperti PC/laptop) atau perangkat mobile (smartphone).

Skrip yang digunakan untuk membangun program berbasis web mobile menggunakan bahasa PHP dan javascript. Banyaknya pengguna yang menggunakan perangkat mobile dan menjadi suatu kebutuhan untuk bisa mengakses informasi dari perangkat mobile seperti smartphone. Web mobile menjadi tren karena banyaknya pengguna yang menggunakan perangkat mobile. Pemrograman berbasis web mobile terus berkembang semakin cepat (Utomo, 2013).

\subsection{Model Waterfall}

Model Waterfall melakukan perancangan perangkat lunak yaitu dengan menggunakan model Waterfall. Model Waterfall dapatdigunakan untuk memenuhi kebutuhan pelanggan yang sudah dipahami dan memungkinkan terjadinya perubahan kebutuhan selama melakukan tahap pengembangan perangkat lunak dengan spesifikasi yang tidak berubah (Rosa \& Shalahuddin, 2013).

Model Waterfall memiliki kelebihan yaitu dapat memperoleh hasil sistem perangkat lunak yang baik karena pengembangan yang dilakukan secara bertahap. Sehingga pengembangan sistem dapat teorganisir. Sedangkan kelemahan dari Model Waterfall yaitu proses pengembangan yang tidak dapat dilakukan secara berulang pada tahapannya dan selain itu kesalahan kecil dapat menjadi kesalahan besar jika kesalahan tersebut tidak diketahui dari awal pengembangan perangkat lunak (Pressman, 2012).

\section{PEMBAHASAN}

\subsection{Rancangan Data Flow Diagram (DFD)}

\subsubsection{Diagram Konteks}

Diagram Konteks atau disebut juga dengan model sistem fundamental yang menggambarkan seluruh elemen dari sebuah sistem atau aplikasi. Keterangan lebih jelas dapat dilihat pada Gambar 1. 


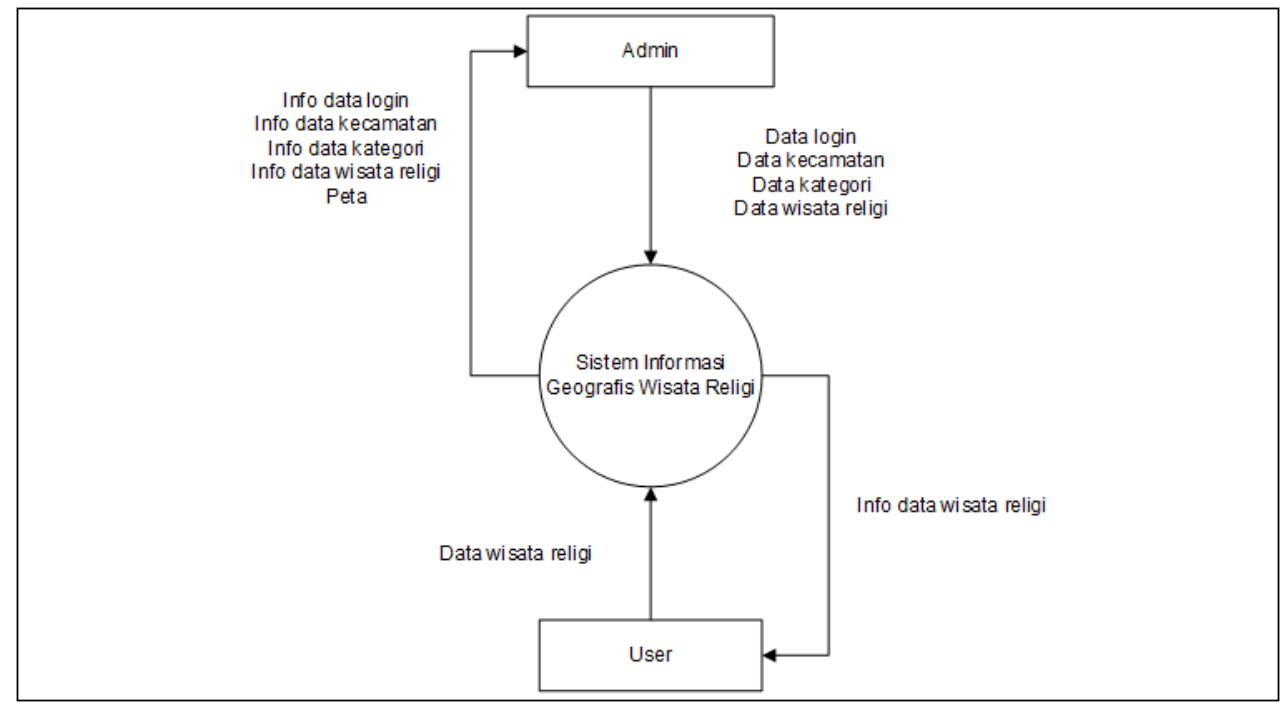

Gambar 1. Diagram konteks

Pada Gambar 1 merupakan gambaran aliran data pada sistem informasi geografis wisata religi berbasis web mobile secara singkat yaitu memiliki dua aktor yaitu admin sebagai aktor yang mengelola data dan user sebagai pengguna biasa. Admin sebagai aktor yang dapat mengelola data login, data kecamatan, data kategori, dan data wisata religi. Sedangkan user hanya dapat mengakses data informasi wisata religi dan peta wisata religi.

\subsubsection{Diagram Dekomposisi}

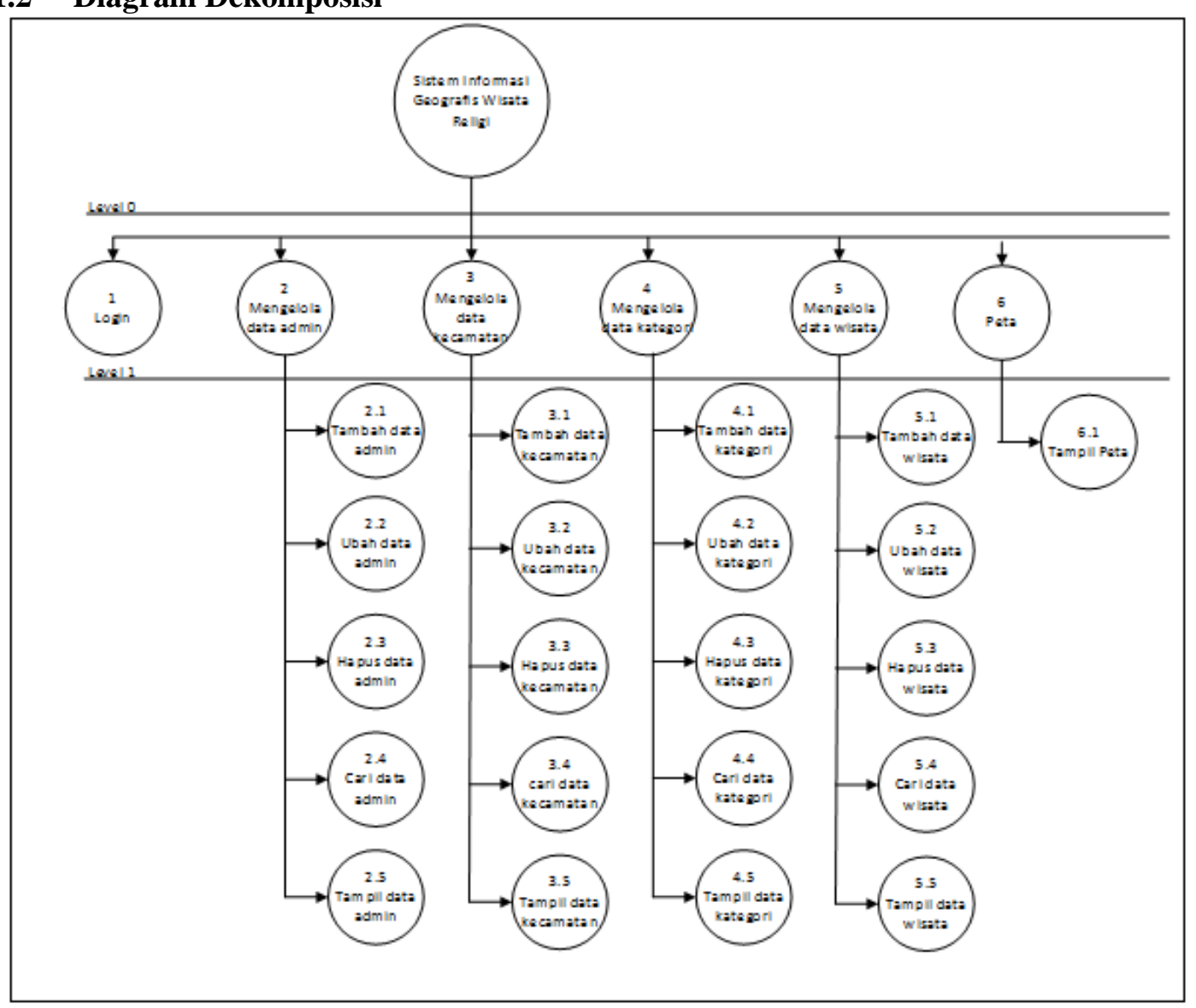

Gambar 2. Diagram dekomposisi 
Pada Gambar 2 diagram dekomposisi dapat ditentukan melalui alur dataflow diagram menurut level nya. Alur dekomposisi Sistem Informasi Geografis Wisata Religi Berbasis Web Mobile menggambarkan aliran diagram sistem informasi geografis wisata religi yang dibangun, pada level 0 sistem dapat mengelola login, mengelola data admin, mengelola data kecamatan, mengelola data kategori, mengelola data wisata religi, dan peta. Masing-masing data memiliki data menu seperti berikut:

1. Mengelola Data admin memiliki menu tambah data, ubah data, hapus data, cari data, dan tampil data.

2. Mengelola Data kecamatan memiliki menu tambah data, ubah data, hapus data, cari data, dan tampil data.

3. Mengelola data kategori memiliki menu tambah data, ubah data, hapus data, cari data dan tampil data.

4. Mengelola data wisata religi memiliki menu tambah data, ubah data, hapus data, cari data dan tampil data.

5. Peta dimana sistem hanya akan menampilkan peta tempat wisata religi.

\subsection{Rancangan Flowchart}

\subsubsection{Flowchart Halaman Free User}

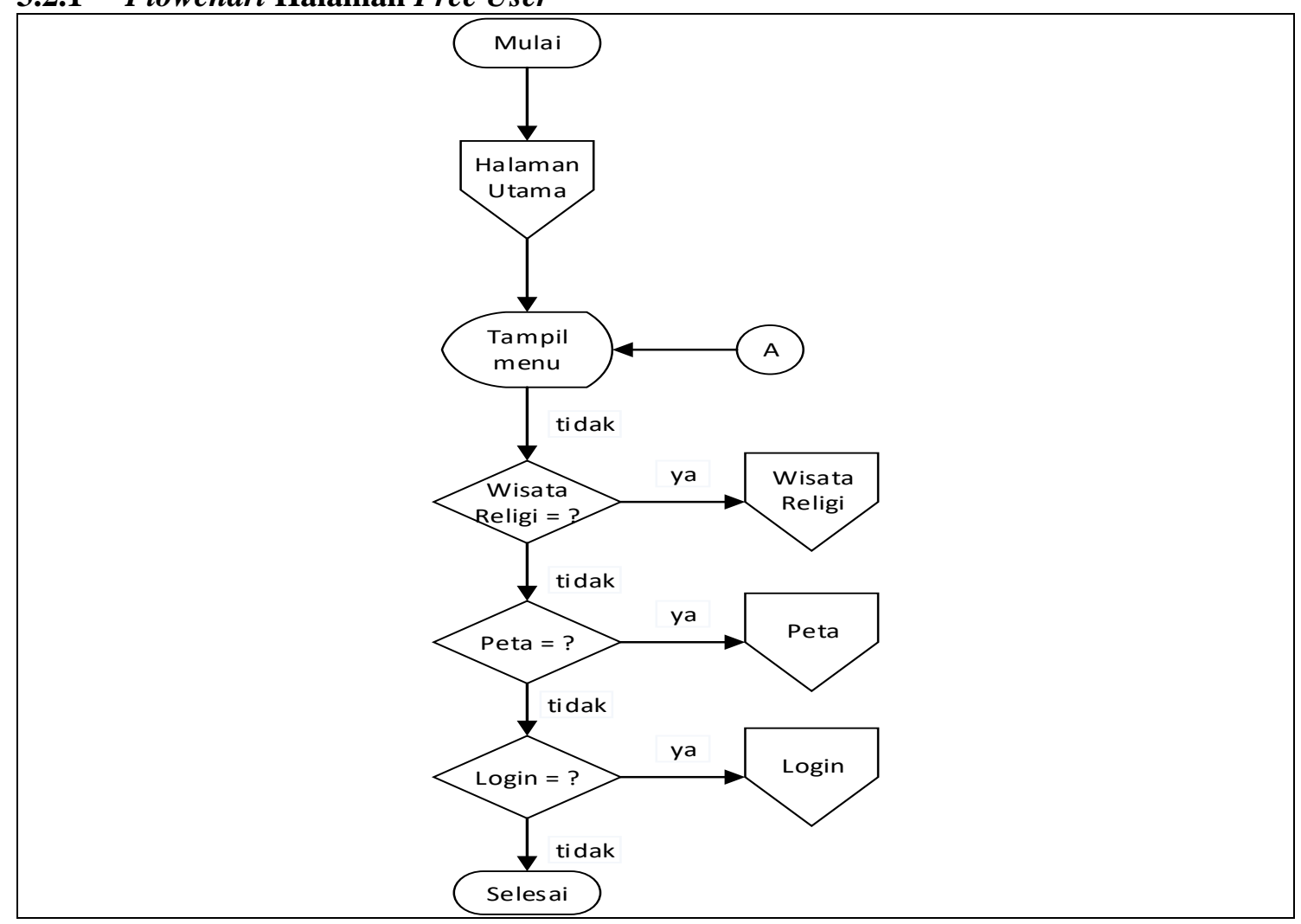

Gambar 3. Flowchart halaman free user

Pada Gambar 3 gambaran jalannya sistem informasi flowchart halaman utama pertama kali menjalankan sistem maka admin dan freeuser masuk ke dalam halaman utama. Pada halaman utama ini juga menjadi halaman freeuser dimana freeuser dapat memilih tiga menu utama yang ada di halaman freeuser diantaranya yaitu menu beranda, menu wisata religi, dan menu peta. Jika freeuser memilih menu beranda maka akan menampilkan halaman beranda. Jika memilih menu wisata religi maka akan masuk kedalam halaman wisata religi dan menampilkan data wisata religi berdasarkan kategori serta mengenai keterangan kategori wisata religi. Jika memilih menu peta maka akan masuk kedalam halaman peta dan menampilkan peta GIS dalam GIS tempat wisata religi. Sedangkan untuk menu login ditujukan hanya untuk admin, dimana jika admin memilih 
menu login maka akan masuk kedalam halaman admin dan menampilkan form untuk menginput data untuk melakukan login.

\subsubsection{Flowchart Halaman Admin}

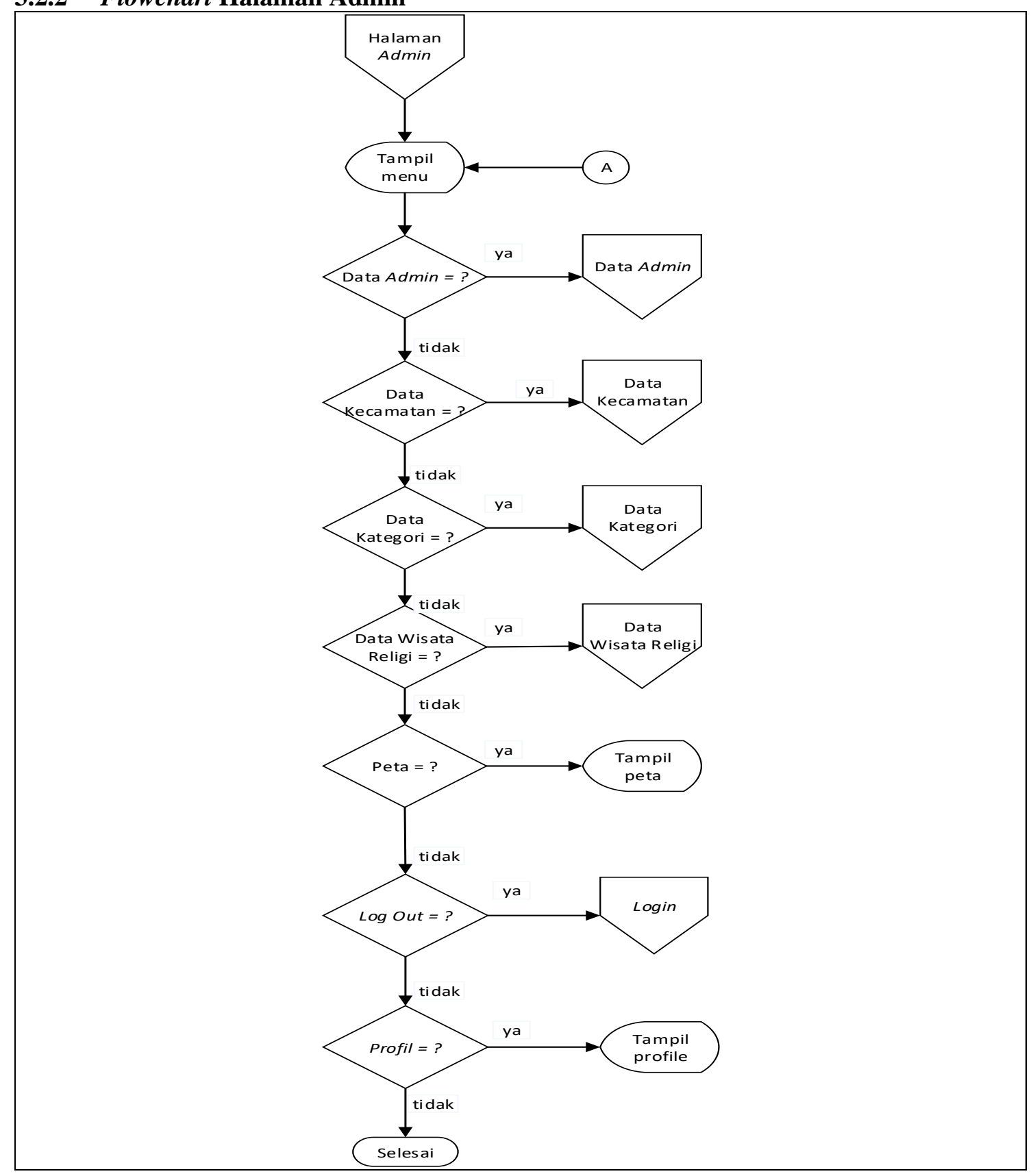

Gambar 4. Flowchart halaman admin

Pada Gambar 4 gambaran jalannya sistem informasi setelah melewati form login admin masuk kedalam halaman admin dimana pada halaman admin akan menampilkan beberapa menu untuk mengakses pengelolaan data admin, Data kecamatan, data kategori, data wisata religi dan logout. Tiap pilihan akan masuk kedalam halaman tiap masing-masing menu pengelolaan data. 


\subsection{Implementasi}

\subsubsection{Tampilan Halaman Wisata Religi}

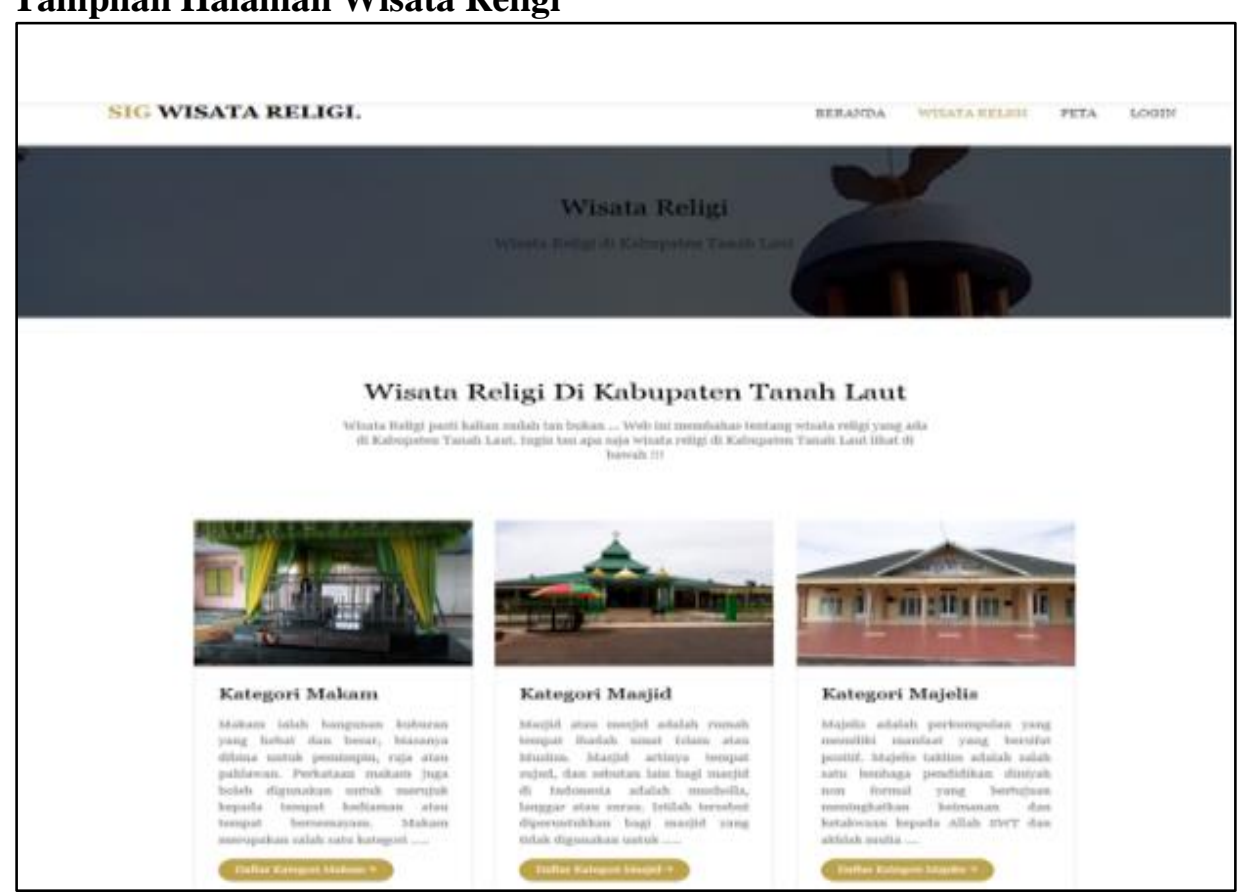

Gambar 5. Halaman wisata religi user

Pada Gambar 5 halaman wisata religi untuk menampilkan gambar dan sedikit penjelasan mengenai masing-masing kategori wisata religi, pada halaman wisata religi tersedia button daftar wisata religi berdasarkan kategori masing-masing.

\subsubsection{Tampilan Halaman Peta Free User}

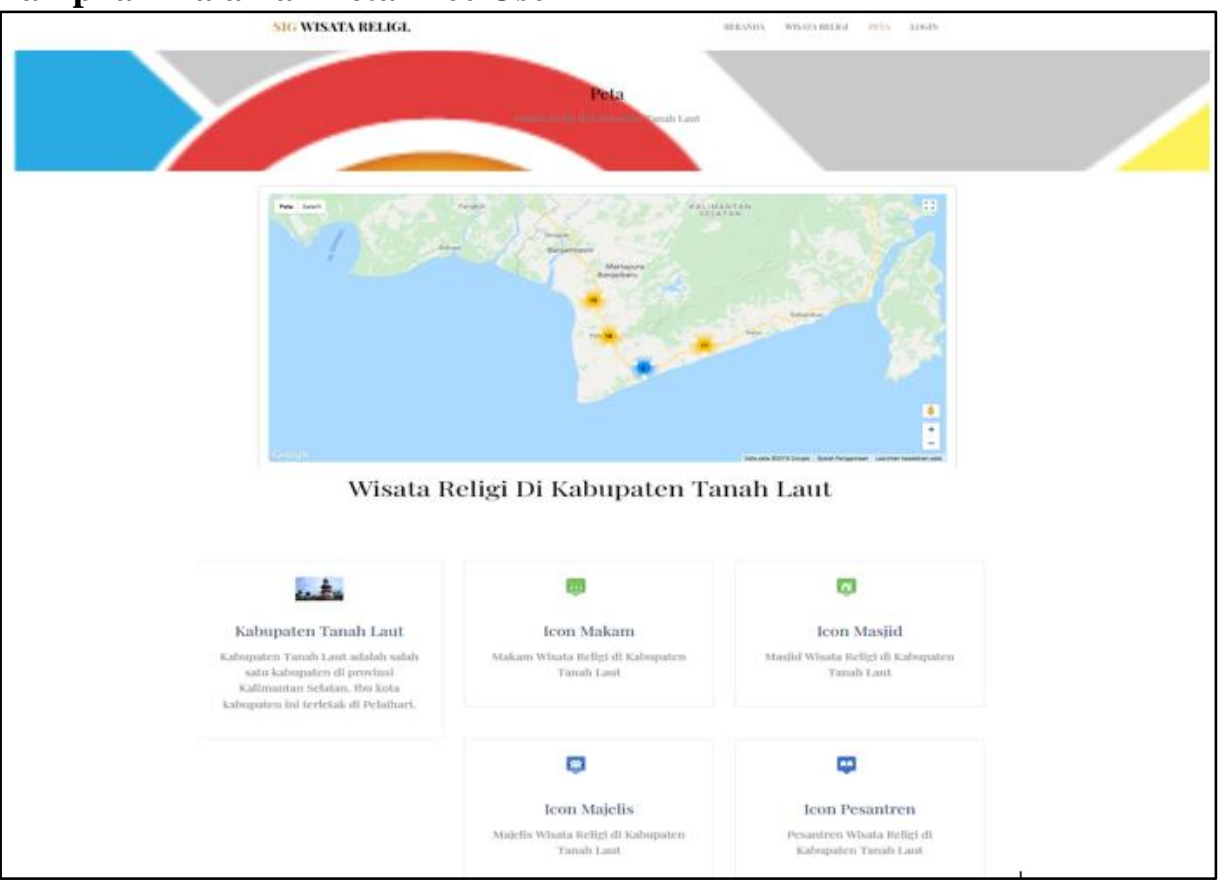

Gambar 6. Halaman peta free user

Pada Gambar 6 menampilkan gambaran halaman peta free user dimana terdapat peta yang menampilkan titik koordinat wisata religi. 


\section{PENUTUP}

\subsection{Kesimpulan}

Kesimpulan yang dapat diambil yaitu telah dibangun Sistem Informasi Geografis Wisata Religi dengan berbasis Web Mobile dirancang menggunakan Data Flow Diagram (DFD), Entity Relationship Diagram (ERD), dan flowchart. Sistem dibangun dengan menggunakan bahasa pemrograman Hypertext Preprocessor (PHP), Java Script dan Hyper Text Mark up Language (HTML). Penyimpanan data menggunakan database MySql.

\subsection{Saran}

Berdasarkan dari pembahasan laporan ini, Saran yang ingin penulis sampaikan untuk pengembangan sistem informasi geografis wisata religi berbasis web mobile yaitu:

1. Sistem informasi geografis wisata religi dapat dikembangkan lagi dengan menambahkan diagram yang dapat menampilkan banyaknya freeuser yang mengakses sistem informasi geografis wisata religi berbasis web mobile.

2. Sistem dapat dikembangkan dengan menambahkan rute pada peta

3. Sistem dapat dikembangkan dengan membuat peta menjadi GIS dalam GIS berdasarkan area kecamatan.

\section{DAFTAR PUSTAKA}

Adil, A. (2017). Sistem Informasi Geografis (I ed.). Yogyakarta: Penerbit Andi.

Chotib, M. (2015). Wisata Religi di Kabupaten Jember. Jurnal Fenomena, 14(2), 206-225.

Irwansyah, E. (2013). Sistem Informasi Geografis : Prinsip Dasar dan Pengembangan Aplikasi. Yogyakarta: Penerbit Digibooks.

Pressman, R. S. (2012). Rekayasa Perangkat Lunak (Pendekatan Praktisi) Edisi 7 : Buku 1. Yogyakarta: Penerbit Andi.

Rosa, A. S., \& Shalahuddin, M. (2013). Rekayasa Perangkat Lunak Terstruktur dan Berorientasi Objek. Bandung: Informatika.

Sari, N. K. A. P., Yasa, I. G. A. S., Darmawiguna, I. G. M., \& Sunarya, I. M. G. (2016). Geographic Information System Wisata Religi Bali Berbasis Web. Kumpulan Artikel Mahasiswa Pendidikan Teknik Informatika (KARMAPATI), 5(1).

Utomo, E. P. (2013). Mobile Web Programming HTML 5, CSS3, JQuery Mobile. Yogyakarta: Andi Publisher.

Wahana Komputer. (2014). Sistem Informasi Geografis Menggunakan ArcGIS. Jakarta: Elex Media Komputindo.

\section{Biodata Penulis}

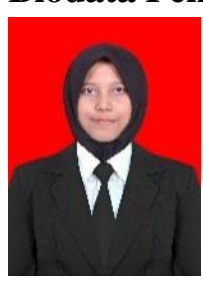

Nur Vinandari, lahir di Pelaihari pada tanggal 22Agustus 1997. Penulis pertama menyelesaikan Sekolah Menengah Atas di SMKN 1 Pelaihari pada tahun 2015 dan melanjutkan pendidikan ke Politeknik Negeri Tanah Laut. Saat ini penulis pertama telah menempuh semester VI di Jurusan Teknik Informatika Politeknik Negeri Tanah Laut dan sedang menyelesaikan Tugas Akhir untuk memperoleh gelar A.Md.

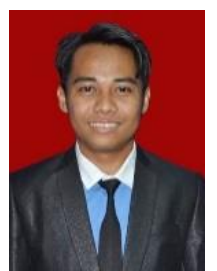

Khairul Anwar Hafizd, lahir di Gambut pada tanggal 1 Juni 1989. Penulis kedua memperoleh gelar S.Kom dalam bidang Informatika STTI pada tahun 2011, kemudian melanjutkan pendidikan Strata 2 di Jurusan Sistem Informasi Bisnis di LIKMI Bandung dan memperoleh gelar M.Kom pada tahun 2014. Selama penulis menempuh pendidikan Strata 2, penulis memfokuskan untuk mengkaji bidang Sistem Informasi terutama yang berhubungan dengan Sistem Informasi Bisnis. Setelah memperoleh gelar Magister, penulis bekerja menjadi Dosen di Jurusan Teknik Informatika Politeknik Negeri Tanah Laut dari tahun 2015 s/d sekarang. 
Muhammad Noor, lahir di Tanah Laut pada tanggal 01 November 1985. Penulis ketiga memperoleh gelar S.H.I dari jurusan Akhwan Al-syakhsiyah di Institut Darllugh Wasyakhsiyah di Universitas Sunan Giri Surabaya (URISURI) dan memperoleh gelar M.H.I pada tahun 2013. Setelah memperoleh gelar Magister Hukum Islam Penulis bekerja menjadi Dosen di Jurusan Teknik Informatika Politeknik Negeri Tanah Laut mulai tahun 2013 s/d sekarang. 